DOI: 10.22616/REEP.2019.025

\title{
A Case of Competence Building - International Student Scientific Mathematics Olympiad
}

\author{
Anna Vintere ${ }^{1}$ Mg. math.; Sarmite Cernajeva ${ }^{2}$ Mg. paed. \\ Latvia University of Life Sciences and Technologies ${ }^{1}$, Riga Technical University, Latvia ${ }^{2}$ \\ Anna.Vintere@llu.lv¹,sarmite.cernajeva@inbox.lv²
}

\begin{abstract}
In the last decade, the concept of competence has been developed and competence-based learning has become the dominant educational approach in Latvia. It poses new challenge also for mathematics studies - to provide opportunities for students to achieve competence and acquire knowledge, values and skills needed for successful professional and fulfilled personal life. The aim of the article is to give insight into International Student Scientific Mathematics Olympiad (ISSMO), organized by Latvia University of Life Sciences and Technologies in order to contribute to the development of students' mathematical and social competence such as effectively communicate with others, cooperatively work in teams. This article describes the methodology of the International Student Scientific Mathematics Olympiad organization, summarizes the experience and analyses the results of the ISSMO of two largest technical universities in Latvia and among so-called Agricultural Universities in Baltic States in 2018. Olympiad is focused on application of mathematics to real-life situations. The results show that solving practical problems requiring the use of other study subjects presents difficulties for all students.
\end{abstract}

Keywords: competence, competence-based education, International Mathematics Olympiad, university education.

\section{Introduction}

UNESCO Report (Learning..., 1996) indicated that education to be organized according to the four basic principles of educational pillars: learn to know - to develop critical thinking, learn methods and instruments to understand world; learn to do - knowledge, values and skills to be able to use the acquired knowledge in everyday life, etc.; learn to live together, to attend and participate in all human activities along with other people; learn to be - knowledge, values and skills for well-being, to develop personality, to make independent decisions, to take responsibility, etc. It poses new challenge also for mathematics studies - promote each individual's opportunities to acquire knowledge, values and skills needed for participation in decision-making as well as knowledge, skills and values to work and live in a rapidly changing world. According to O. Yusupova and L. Ibyatova (2018), proficiency in mathematics is as an essential precursor to success in modern society necessary to ensure highly qualified specialists for the knowledge-based, skill and technology-intensive industries (Yusupova, Ibyatova, 2018).

Throughout human history mathematics plays a key role in intellectual and professional development and seen as an integral part of human culture, because of creating an understanding of the surrounding world, providing a scientific basis and ensuring the development of technology. Mathematical studies have a decisive role in education, forming systemic thinking, form the person's cognitive abilities, as well as logical thinking and influence the teaching process of other disciplines (Yusupova \& Ibyatova, 2018). Complex problem solving, critical thinking, creativity, decision making, cognitive flexibility these are the competences most often referred to as a key element of sustainable development, and they can be developed through mathematical education (Vintere, 2018).

Over the last decade mathematical competence has become one of the most important educational priorities at the European policy level. The new competence-based teaching/learning of mathematics differs in that the student must be able to recognize the problem, to choose the appropriate method for solving the problem, to apply formulas in new atypical situations and to evaluate the importance of problem solving. A. Vorobjovs emphasizes the most important factors influencing mathematical competence: learning environment (including physical, emotional and extracurricular), the aims (students' aims, society and employers aims, aim of programme and standard), content of study materials and teaching/learning process - teachers' professionalism. Balancing these factors educator can contribute to increasing students' mathematical competence (Vorobjovs, 2017). 
Students' analytical skills develop if the study process is based on the student-centred and self-directed study approach using also the distant education forms of studies. Modern applied mathematics assumes the combination in the study process of traditional and innovative methods, tools, forms of learning as integrated lectures, professionally oriented set of practical exercises with the use of the computer, the realization of interdisciplinary connections at the level of knowledge and analytical work to increase the professionally significant qualities (Korolova, Zeidmane, 2016).

In the last decade, the concept of competence has been developed and competence-based learning has become the dominant educational approach in Latvia (LV). Competence-based approach is a response to the demand of the labour market, thus making formal education more relevant to society development requirements, focusing on the students' abilities to develop knowledge, values, and attitudes necessary to address complex issues with what they will face in their future personal lives and professional careers.

According to the European Qualifications Framework for Lifelong Learning, competences include cognitive, functional, ethical, and personal dimensions including development of the knowledge, values, skills and attitudes (Towards a European..., 2005). According to the National Development Plan of Latvia for 2014-2020 (National Development Plan..., 2012) Action Plan "Competence Development", a person needs different competences (a set of knowledge, skills and attitudes). In Latvia, the concept competence is understood as the readiness of an individual to live in a changing, changing world; ability to use knowledge, skills and attitudes in solving problems in changing, real life situations; the ability to adequately use learning outcomes in a given context (education, work, personal or socio-political).

From the point of view of the four basic pillars of learning, all learners should acquire at least the following competences: collect, select, process and manage information; master instruments of knowing and understanding; effectively communicate with others; adapt oneself to changes in life; cooperatively work in teams; resolve conflict through peaceful dialogue and negotiation (Rychen, Tiana, 2004). A. Zeidmane and V. Duka (2014) researches and recommends to improve the students' independent studies using information communication technologies and using e-study environment to increase the mathematical competence.

In order to contribute to the development of mathematical education in line with above, as well as to promote mathematical and social competence building, Latvia University of Life Sciences and Technologies (LLU) and Siauliai University (SU) from Lithuania (LT) in 2011 within the framework of the Latvia-Lithuania cross-border cooperation project " Cross-border network for adapting mathematical competences in the socio-economical development" launched a sustainable initiative: International Student Scientific Mathematics Olympiad (ISSMO). Why sustainable? Although the project is completed in 2013, the Olympiad is held every year and the number of participating universities is steadily rising. The main objective of these Olympiad - the encouragement of best students for the adaptation of knowledge and skills by gathering them together and by setting the conditions to share scientific and cultural experience.

The aim of the article is to give insight into International Student Scientific Mathematics Olympiad, organized by Latvia University of Life Sciences and Technologies in order to contribute to the development of students' mathematical and social competence such as effectively communicate with others, cooperatively work in teams. This article describes the methodology of the International Student Scientific Mathematics Olympiad organization, summarizes the experience and analyses the results of the ISSMO.

\section{Methodology}

By the tradition International Student Scientific Mathematics Olympiad is organized by Department of Mathematics of LLU in cooperation with Siauliai University. Students who good at mathematics, interested in solving specific problems as well as all who want to try their hand at math competitions are invited to participate in ISSMO.

ISSMO consists of two parts: the individual competition and work in groups. The level of the individual tasks does not exceed high school knowledge but may also be used knowledge acquired at the university. All tasks reflect a real-life situation, have an interdisciplinary approach (they include knowledge of other subjects, e.g., physics or statistics) and focused on ability to ask and answer questions in and with math and the ability to deal with and manage math language and tools. They include Jigsaw tasks, multiple 
choice questions - choose the right one, answers where need to mark all possible answers, briefly task solutions or drawings, tasks with an open answer - explanations, etc.

The assessment is based upon previous level of preparation, creativity, analytical thinking and elementary knowledge of mathematical theory that in generally available in the textbooks and most library reference collections. The individual tasks assessment is done mainly by teaching staff from LLU, SU and Estonian University of Life Sciences (EMU). It takes place immediately after the competition, so winners could be announced and awarded at the same day. Usually winners are determined in two categories - individual competition and teams.

Greater attention usually paid to work in groups of five - seven students (from different universities). Each group is given a practical problem, which had to be solved and presented. As there are also participants from Lithuania, Estonia (EE) as well as LLU International students including Erasmus+, it is necessary to have good English skills to work in groups. Presentation also has to be held in English.

Groups work presentations are assessed by participating universities' teachers. ISSMO work in groups assessment criteria include three directions:

- problem solution: mathematically correct problem solution and innovative or an interesting solution;

- the quality of the presentation: explanation of the problems and solutions and an interesting approach in the presentation - models, drawings, performance;

- cooperation - participation of the entire group in the presentation.

Groups are also given an additional task - to share experience of mathematics studies in their educational institutions, identify similarities and differences, as well as develop proposal for a mathematics studies advancement. Group work is a very effective method in mathematics, because it teaches to cooperate, make decisions, from which, whereas, accomplishments of all group depend on.

The following section of this article summarizes and analyses the results of the Olympiad by the universities, year and countries. A detailed overview is provided of the results of 2018 Olympiad.

\section{Results and discussions}

In 2018 Olympiad took place for the seventh time and there was a wide range of participants. Latvia has been represented by students from almost all universities: Latvia University of Life Sciences and Technologies, University of Latvia (LU), Riga Technical University (RTU), Ventspils University College (VeA), Vidzeme University of Applied Sciences (ViA), Liepaja University (LiepU), Daugavpils University (DU) and Rezekne Academy of Technologies (RTA). From Lithuania, Siauliai University and Aleksandras Stulginskis University (ASU) participate in the Olympiad, from Estonia EMU. The number of ISSMO participants is summarized in Table 1. It shows also the dynamic of rising the number of participating universities.

Table 1

The number of ISSMO participants

\begin{tabular}{|c|c|c|c|c|c|c|c|c|c|c|c|c|}
\hline \multirow{2}{*}{ Year } & Total & \multicolumn{9}{|c|}{ LV } & \multicolumn{3}{c|}{ LT } & EE \\
\hline & & LLU & RTU & VeA & ViA & LiepU & LU & DU & RTA & SU & ASU & EMU \\
\hline 2011 & 55 & 35 & & & & & & & & 20 & & \\
\hline 2012 & 55 & 35 & & & & & & & & 20 & & \\
\hline 2014 & 29 & 13 & 8 & & & & & & & 9 & & \\
\hline 2015 & 59 & 26 & 16 & 3 & & & & & & 14 & & \\
\hline 2016 & 56 & 23 & 6 & 3 & 11 & & & & & 13 & & \\
\hline 2017 & 64 & 29 & 3 & 3 & & 3 & 7 & & & 11 & 5 & 3 \\
\hline 2018 & 37 & 7 & 5 & 3 & 2 & & 2 & 1 & 1 & 9 & 3 & 3 \\
\hline
\end{tabular}

Table 2 summarizes average and maximum points of individual competitions by years. As it is seen, RTU shows the best results almost every year. It should be noted that the students of the Faculty of Physics and Mathematics from the University of Latvia participate in the Olympiad, with specialization in mathematics. Surprisingly, but their results are comparable to non-mathematicians. 
Table 2

ISSMO individual competition results

\begin{tabular}{|c|c|c|c|}
\hline Year & University & Average & Max \\
\hline \multirow[t]{2}{*}{2012} & LLU & $13.4(30)$ & $24(30)$ \\
\hline & $\mathbf{S U}$ & $13.5(30)$ & $25(30)$ \\
\hline \multirow[t]{3}{*}{2014} & LLU & $17.4(30)$ & $25(30)$ \\
\hline & RTU & $21.1(30)$ & $26(30)$ \\
\hline & $\mathrm{SU}$ & $16(30)$ & $26(30)$ \\
\hline \multirow[t]{5}{*}{2016} & LLU & $20.5(40)$ & $38(40)$ \\
\hline & RTU & $30.5(40)$ & $40(40)$ \\
\hline & $\mathrm{VeA}$ & $26.3(40)$ & $32(40)$ \\
\hline & ViA & $17.8(40)$ & $31(40)$ \\
\hline & SU & $19.2(40)$ & $29(40)$ \\
\hline \multirow[t]{8}{*}{2017} & LLU & $11.9(30)$ & $14.5(30)$ \\
\hline & RTU & $17.3(30)$ & $19(30)$ \\
\hline & LU & $16.8(30)$ & $21(30)$ \\
\hline & VeA & $15(30)$ & $16(30)$ \\
\hline & LiepU & $8.3(30)$ & $12(30)$ \\
\hline & $\mathrm{SU}$ & $11.5(30)$ & $14.5(30)$ \\
\hline & ASU & $9.6(30)$ & $11.5(30)$ \\
\hline & EMU & $14.7(30)$ & $19(30)$ \\
\hline \multirow{8}{*}{2018} & LLU & $7.3(24)$ & $14(24)$ \\
\hline & RTU & $12.8(24)$ & $20(24)$ \\
\hline & $\mathbf{L U}$ & $20.5(24)$ & $21(24)$ \\
\hline & $\mathrm{VeA}$ & $13(24)$ & $14(24)$ \\
\hline & ViA & $19(24)$ & $21(24)$ \\
\hline & SU & $9.3(24)$ & $19(24)$ \\
\hline & ASU & $5(24)$ & $7(24)$ \\
\hline & EMU & $10(24)$ & $12(24)$ \\
\hline
\end{tabular}

Figure 1 illustrates the overall assessment of tasks for 2018, but figure 2 - assessment by country. The first five tasks were, so-called, one-point tasks - very simple with the given answers. Tasks 6 to 8 were three-point tasks in which the answer had to be based on calculations.

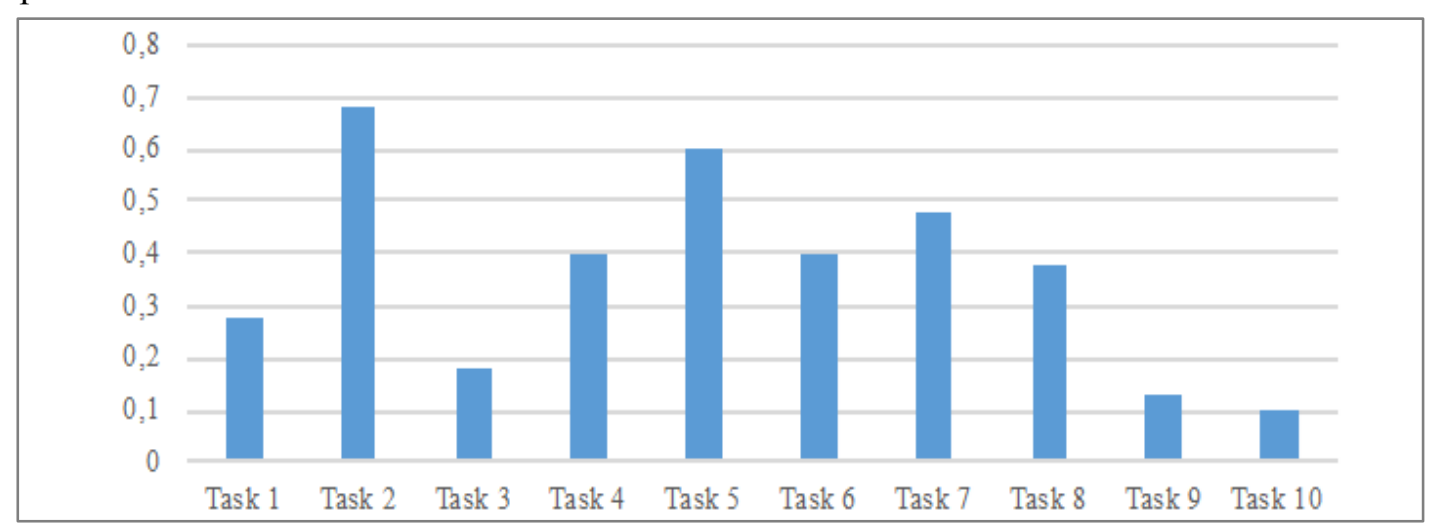

Figure 1. Overall assessment of tasks for 2018.

Task 9 included physics knowledge, because it was necessary to calculate the average speed. Only $13 \%$ of all students answered the correct answer. In general, the answer is given in $67 \%$ of cases. To solve 
this problem, students had to know how the average speed of the movement is calculated, but students do not pay attention to it, and $22 \%$ of the cases they are looking for the arithmetic mean. $11 \%$ of students do not start solving this task at all.

Task 10 was also practical - calculate how large the cleaned area of the car's windscreen wipers is. This task was based on geometric knowledge. Right answers gave only $10 \%$ of students, but $32 \%$ of students do not start solving this task at all. Task 10 has focus on development of the ability to deal with and manage math language and tools. During the Olympiad students were allowed to use formula sheets which contains also formulas needed for calculation of required are. In this case the decisive role was the creation of a drawing that describes students' competence understand and use different mathematical objects and situations, choose or change different representations. In both of these tasks 9 and 10. 5 points were awarded for the correct answer.

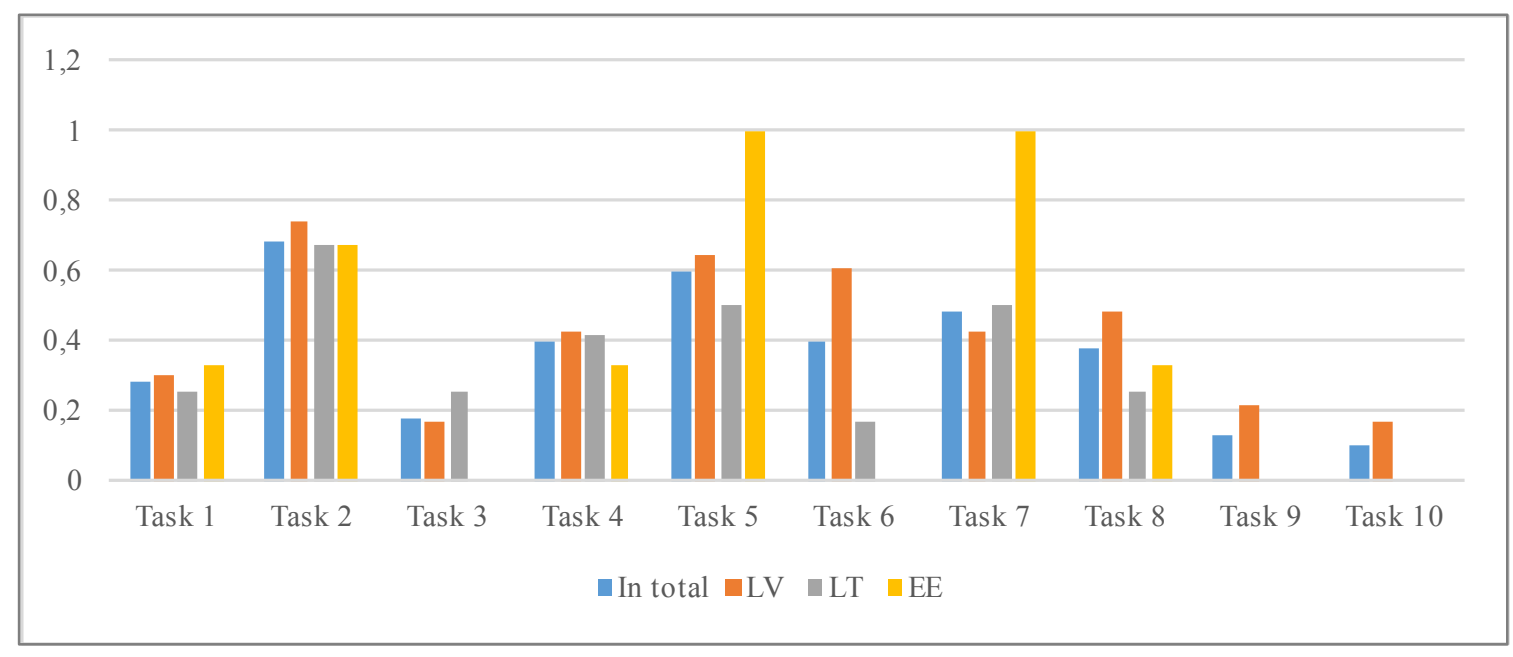

Figure 2. Total 2018 task assessment by country.

Comparing the results of 2018 (Figure 3) between the two largest technical universities in Latvia: LLU and RTU, it is evident that RTU students' achievements in this Olympiad are higher than those of LLU.

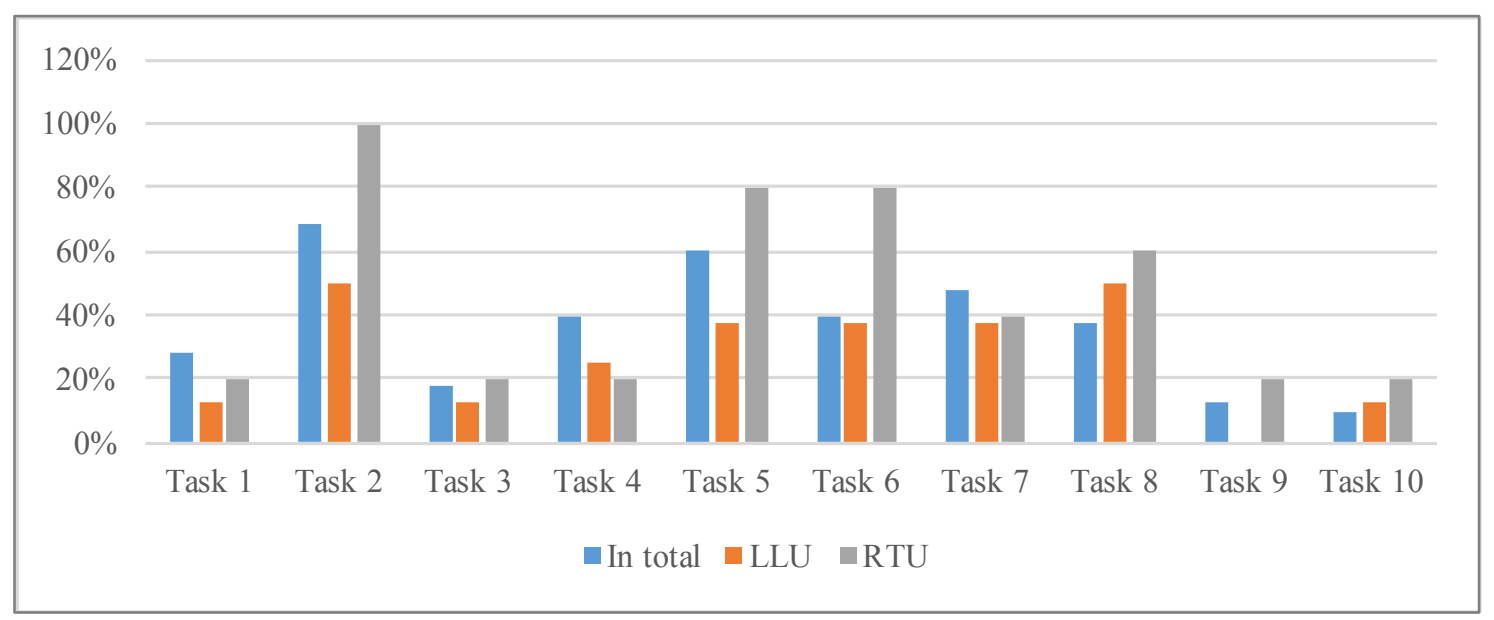

Figure 3. Comparison of results of LLU and RTU.

Results in figure 4 show that among the so-called agricultural universities in the Baltic States, Estonian University of Life Sciences has the highest achievements, the lowest - Aleksandras Stulginskis University.

Groups are also given an additional task - to share experience of mathematics studies in their educational institutions, identify similarities and differences, as well as develop proposal for a mathematics studies advancement. Gathering of students thought, mathematics study process evaluation can be divided into four components: mathematics studies organization, acquired mathematical knowledge application / usefulness, teaching staff and building professional and social competences. 


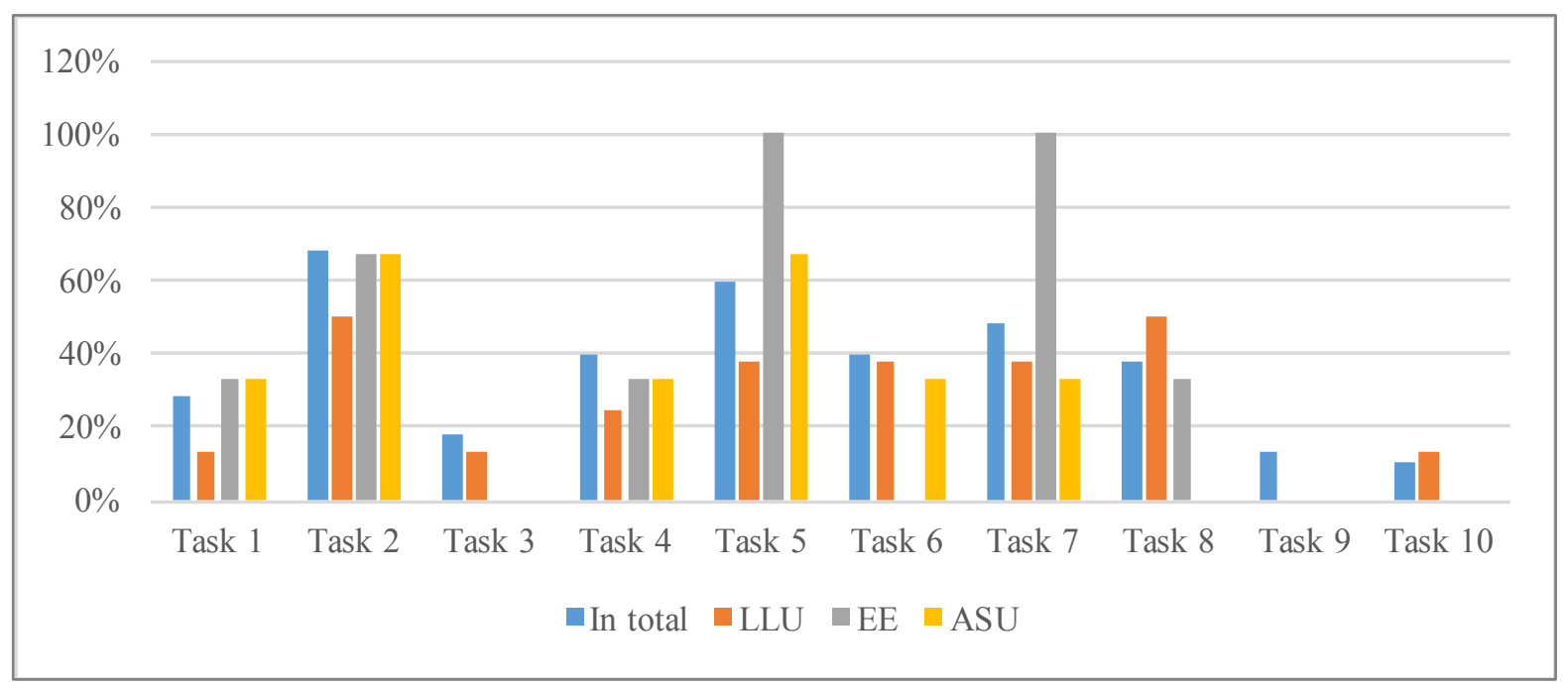

Figure 4. Comparison of the results of the so-called Agricultural Universities in the Baltic States.

Common to the higher mathematics studies - homework (individual work), tests, practical work in relatively small groups as well as the availability of electronic training material (e-learning training platform, etc.). There are also found some differences. In LLU mathematics courses include also laboratory work where students learn to use MathCad / Matlab. But in Riga Technical University home works are being evaluated and assessment provide extra points. They also have the exam during the semester. Students appreciate it, because it provides an opportunity easier to pass course. High school math refreshing courses which are organized in LLU and RTU are also very high appreciated by the students.

There are two approaches in evaluation of acquired mathematical knowledge application / usefulness:

- mathematics studies based on practical approach, are designed for use in math skills to solving real problems;

- theoretical approach to student assessment contributes to general skills (as students said "more solid background").

LLU and RTU students see the need to study mathematics but students from the Siauliai University in doubt about math applications in the future/ in specialty. At same time for Vidzeme University of Applied Sciences students only a few themes seem interesting and useful in their chosen profession.

In Siauliai University students appreciate as the most valuable asset students' friendly study environment, technology availability, good relations with teachers, as well as the fact that the teachers are very nice and the study process gives a lot of very good examples. Ventspils University College students are surprised that the teacher after the lecture not only asks whether the students all understood and whether there are any suggestions or wishes, but, above all, take into account the students' recommendations. But LLU students are worried that sometimes teachers "rush through the lecture" the information is given too fast.

Students' perception of building professional and social competences of can be illustrated by students' statements: Mathematics helps us to improve how we think and how we solve problems; mathematics improves technical thinking and overtake obstacles; gives solid background; should be more people to study mathematics! Mathematics is cool!

Work in groups also includes development of proposals for a mathematics studies improvement. To improve mathematical studies in all universities mentioned it would be necessary: organize extra courses to refresh school mathematics, associate mathematics with daily life, use more visual materials, lecturers should learn more examples from life and make interactive lessons, develop encouraging system to learn mathematics, in study programs include history of mathematics, organize excursions to companies, invite interesting people to tell about mathematics in their professional and personal life, celebrate math-related events.

\section{Conclusions}

- The main benefits of the International Student Scientific Mathematics Olympiad are: interest in mathematics promotion among young people; strengthening education obtained at school, 
provide opportunity for its creative application; encouragement for students to think "out of the box"; development of cooperation between young people with similar interests.

- Providing opportunities for pupils and students to communicate about mathematics, is cultivated a supportive environment that can deepen mathematics understandings and meaningful studies at universities. It promotes the interest of mathematics between students, giving a creative opportunity to use it, promote cooperation and provide opportunity to share scientific and cultural experience as well as to improve professional and social competence.

- International Student Scientific Mathematics Olympiad consists of two parts: the individual competition and work in groups. Greater attention is paid to work in groups. Group work is a very effective method in mathematics, because it teaches to cooperate, make decisions, from which, whereas, accomplishments of all group depend on.

- Comparing the results among the countries, the highest achievements have Estonians. Analysing the achievements of LLU and RTU, one can see that RTU demonstrates a higher level of achievement than LLU. EMU has the highest, but ASU - the lowest achievements among the so-called agricultural universities in the Baltic States.

- Solutions to practical problems where the knowledge acquired in other study subjects is applied have created the most serious problems for the students. Its proves that mathematics studies at universities should focus not on so called procedural knowledge and step-by-step calculations using certain formulas and mathematical operations, but to application of mathematics to reallife situations as well as interpretation of results.

\section{Bibliography}

1. Korolova J., Zeidmane A. (2016). Applied Mathematics as an Improver of Analytical Skills of Students. In V. Dislere (Ed.), The Proceedings of the International Scientific Conference Rural Environment. Education. Personality (REEP), 9. Jelgava: LLU TF, 323-327. Retrieved from http://lufb.llu.lv/conference/REEP/2016/Latvia-Univ-Agricult-REEP-2016proceed2255-808X.pdf

2. Learning: The Treasure Within. (1996). Report to UNESCO of the International Commission on Education for the Twenty-first Century. Paris: UNESCO Publishing. Retrieved from http://www.unesco.org/education/pdf/15_62.pdf

3. National Development Plan of Latvia for 2014-2020. (2012). Riga: Saeima. Retrieved from http://www.pkc.gov.lv/sites/default/files/images-

legacy/NAP2020\%20dokumenti/NDP2020_English_Final.pdf

4. Rychen D.S., Tiana A. (2004). Developing Key Competencies in Education: Some Lessons from International and National Experience. Geneva: UNESCO-IBE, Studies in Comparative Education.

5. Towards a European Qualifications Framework for Lifelong Learning. (2005). Brussels, Belgium: European Commission. Retrieved from http://www.voced.edu.au/content/ngv\%3A30220

6. Vintere A. (2018). A constructivist approach to the teaching of mathematics to boost competences needed for sustainable development. Rural Sustainability Research, 39(334). Scientific Journal of Latvia University of Life Sciences and Technologies, Jelgava, Latvia: LLU. Retrieved from https://content.sciendo.com/abstract/journals/plua/39/334/article-p1.xml

7. Vorobjovs A. (2017). Adolescents' Mathematical Competence Formation Influencing Factors. In V. Dislere (Ed.), The Proceedings of the International Scientific Conference Rural Environment. Education. Personality (REEP), 10. Jelgava: LLU TF, 315-320. Retrieved from http://llufb.llu.lv/conference/REEP/2017/Latvia-Univ-Agricult-REEP-2017_proceedings.pdf

8. Yusupova O., Ibyatova L. (2018). New approaches in mathematics education: the regional development concept of mathematics education. In V. Lubkina (Ed.), Proceedings of the International Scientific Conference Society. Integration. Education, 1, 590-599. Retrieved from http://journals.ru.lv/index.php/SIE/article/view/3230/2989

9. Zeidmane A., Duka V. (2014). Use of IT programs and tools for organizing independent studies in mathematics e-environment. In V. Dislere (Ed.), The Proceedings of the International Scientific Conference Rural Environment. Education. Personality (REEP), 7. Jelgava: LLU TF, 255-262. Retrieved from http://lufb.llu.lv/conference/REEP/2014/Latvia-Univ-Agricult-REEP-2014proceedings.pdf 